Ethnic Conflict Regulation Through Territorial Autonomy A Configurational Analysis of Success and Failure

-Draft-

Felix Schulte

Institute for Political Science, Heidelberg University, Heidelberg, Germany;

felix.schulte@ipw.uni-heidelberg.de 


\section{Ethnic Conflict Regulation Through Territorial Autonomy - A Configurational Analysis of Success and Failure}

Territorial autonomies (TA) are increasingly implemented as tools for regulating ethnic conflicts. Since there are successful as well as failed cases, the ongoing debate about a general conflict-solving potential is not a very fruitful one. The article turns towards the analysis of various factors affecting the success and failure of conflict regulating autonomies. It is argued that autonomy consolidation requires specific conditions which support the process of mutual recognition between ethnic groups. Two causal models are developed and tested on a global data set on all conflict regulating autonomies using a two-step Qualitative Comparative Analysis (QCA). It is found that a combination of low horizontal inequalities, a high scope of autonomy, inclusive institutions and international support lead to autonomy success whereas persistent inequalities, a low scope of transferred competencies and exclusive institutions result in a return to violent strategies. One important implication of these findings is that favorable conditions for post-conflict institutional engineering can, at least to some extent, be created.

Keywords: Territorial Autonomy, Institutional Engineering, Ethnic

Conflict, $Q C A$ 


\section{Introduction}

Most ethnic conflicts are struggles for self-determination by territorially concentrated minorities in majority-dominated nation states. To appease highly emotional separatists and maintain sovereignty at the same time, governments often offer territorial autonomy (TA) to ethnic groups. However, TA are no panacea for regulating ethnic conflicts. Self-rule for Jammu \& Kashmir in India, for Philippines Mindanao or for the Chittagong Hill Tracts in Bangladesh has not led to a peaceful ethnic co-existence. Current research efforts mainly revolve around one central question: Are autonomy reforms a mean to end ethnic conflicts? Scholars are basically divided into two camps: One the one hand the proponents, arguing that regional autonomy can be a suitable solution for multi-ethnic societies (Ghai, 2000; Wolff, 2013), and on the other hand the critics, arguing that autonomy fosters separatist tendencies (Meadwell, 2009; Chapman \& Roeder, 2007). Currently, this debate is far from being resolved (Cederman, Hug, \& Wucherpfennig, 2015; Tranchant, 2016). Since we find successful examples such as South Tyrol or Gagauzia as well as failed cases, this general discussion will not reveal a clear result. Working on a clearer picture, we argue that a more fruitful approach is to analyze conditions of success and failure. We develop a theoretical argument that highlights the importance of ethnic recognition for institutional conflict regulation. Framework conditions that support the process of mutual recognition enhance the chance of successful autonomy consolidation. Conversely, conditions that hinder this process lead to autonomy failure and ongoing secessionist conflict. A multitude of structural and actor-centered factors is analyzed for their causal effect using a two-step QCA analysis. The results offer two important findings for current debates. First, favorable and unfavorable conditions for the success of institutional reforms in post-war societies can indeed 
be identified. Secondly, at least some of these conditions can be modified by practitioners.

\section{Theoretical argument}

Social psychologists support the argument that people have a basic need for a positive self-esteem and strive for recognition of their identity (Burton, 1997; Kelman, 2007). Since identity is also based on belonging to social groups, it is highly important which status in-groups have in comparison to out-groups. Group members seek to achieve positive self-esteem by positively differentiating their ingroup from a relevant out-group on some valued dimension. If a group sees no adequate chance to react to a perceived identity threat, it will use a violent strategy against the identified perpetrator as a last resort (Tajfel \& Turner, 1979; Gurr, 1993). When the group an individual identifies itself with is threatened with injustice and deprivation, there is a shift of the perceived problem from being a political issue to a personal affront. The person is easily mobilised to take part in collective action. The more deeply these perceptions are felt, the more they are linked to group survival, the more intense the conflict that is potentially generated. Since language, religion and historicity are dominant sources of identity, the need for recognition is particularly high for ethnic groups. The core of ethnic conflicts lies in a feeling of non-recognition of cultural identity. The formation of nationstates has led to an organization of political power along ethnic categories that often implies exclusion and thus non-recognition. Self-determination movements are the consequence, which have increased sharply with the emergence of new nation states (Sambanis, Germann, \& Schädel, 2017; Wimmer, 2013). Ethnic recognition can be achieved through institutions that enable empowerment or inclusion. TA provides territorially concentrated groups with executive powers over a range of matters. By providing ethnic groups with a degree of autonomy over political and

cultural issues the central state recognises the legitimacy of these identities and 
affords these minorities a sense of security that the central government will not interfere in group internal affairs. While literature finds strong evidence for a positive effect of such accomodative institutions (Cederman, Gleditsch, \& Wucherpfennig, 2017; King \& Samii, 2017; Lijphart, 1968; McGarry \& O’Leary, 1993), it remains unclear under which circumstances such institutions consolidate and ultimately lead to peaceful co-existence. Recognition between hostile groups is an extremely difficult task that can hardly be achieved by simply implementing institutional reforms. The process of mutual recognition is fostered or hindered by certain framework conditions that create restrictions or incentives. Autonomies consolidate and provide for mutual recognition, if certain framework conditions are in place that facilitate the process of mutual recognition. Autonomy reforms culminate in secession wars when unfavourable conditions hinder the process of mutual recognition. In the next section we present theoretically meaningfull structural and actor-based factors.

\section{Conditions enabling for ethnic recognition}

If empowerment leads to recognition which in turn prevents a group from taking further actions for self-determination, it should thus be highly relevant for the affected group how autonomous it can act. It is assumed that a 1) high scope of autonomy is a decisive condition for autonomy consolidation. The more regulatory areas the ethnic group can decide on, the greater the 'contribution' to a positive group identity, the more likely claims for statehood are dropped. 2) Persistent horizontal inequalities cause a feeling of non-recognition which is perceived as highly unfair. Political, economic, social and cultural asymmetries are transformed into grievances through group comparisons (Stewart, 2008; Gurr, 1970). The sentiments of relatively deprived groups who find their status unfair eventually crystallize into firm conviction that their group status can be rectified only through collective action, and, eventually independence (Cederman, Gleditsch, \& Buhaug, 
2013). In 3) democracies, political conflicts are managed on basis of formalized rules. Since autonomy solutions are hardly needed in the context of consolidated democracies, democratization processes need to be considered. Paradoxically, measures to promote peace do not always promote democracy, and vice versa (Zürcher, 2013). Autonomies, however, separate hostile groups both spatially and institutionally. The consociational Achilles heel, that is mutual blockades, is largely avoided. In contrast, ethnic self-rule can lead to a higher degree of participation and legitimacy and produces cooperation incentives which may have a pacifying socialization effect (Papagianni, 2009; Henderson \& McEwen, 2010). An additional level of authority makes the struggle for control of the central state become less intense and prevents an excessive concentration of power and thus the hegemony of a dominant group (Horowitz, 1985). Inclusive institutions, such as 4) proportional representation systems and 5) decentralization create incentives to bargain and limit power concentration (Bakke, 2015; Gherghina \& Jiglău, 2016). Institutions which encourage cooperative relationships at the central government level are likely to stabilize TA by improving inter-group relationships. While PR and decentralization provide for inclusion in a more or less direct way, 6) rule of law is a prerequisite for this in a very fundamental manner. It is the rule of law that protects minority rights from the tyranny of the majority and allows the legal recognition of ethnic identity (Malloy, 2013; May, Modood, \& Squires, 2004). 7) International and regional organizations can help to turn zero-sum games into positive sum-games and change perceptions through incentives or pressure. If an international organization is involved in the implementation of an institutional reform, it will monitor its consolidation. The deepest intervention undertaken by international organizations involves mandated peace-keeping and the provision of an international transitional authority (Hultman, Kathman, \& Shannon, 2013; Walsh, 2018). International organizations can change perceptions through 
incentives and offer a forum where information can be exchanged. This prevents the emergence of dangerous security dilemmas. External interventions end after a certain period of time. However, it takes years for post-conflict institutions to be implemented and operational. Ethnic groups need continuous support from external actors through the 8) international integration of the autonomy in international or regional organizations. If a TA becomes part of the international community, its special status manifests itself. The arrangement is externally recognized by other sub-state or state actors. The continuous exchange of information within a reliable negotiating framework with established procedural rules creates transparency, reduces uncertainties and encourages to cooperate (Caporaso, 1992; Russett \& Oneal, 2001). This is particularly true when both entities belong to the same organization. If mere demands for self-determination have been made, group members will find it little difficult to accept the autonomy system. If this goal was pursued peacefully, there is a great chance that groups recognize each other as parts of the state's society. However, if the 9) conflict strategy included secessionist claims, then autonomy is only a second choice that does not correspond to the actual goal. In addition, if the group used a violent strategy that was answered by the central government using the same means, reconciliation is significantly more difficult. This hinders mutual recognition and makes the success of an autonomy system less likely. Mutual recognition hinges strongly on actions of the actors involved. A key role play the policy orientation of political parties, which provide a framework for behavior and preferences. 10) Nationalist parties advocate centralization and cultural homogeneity, and trigger ethnic polarization (Gherghina, 2009). Literature points to 11) diasporas as important catalyst providing moral and logistical support and increasing the probability of separatist demands (Gurses, 2015; Kapur, 2010). Diaspora groups and kin states favor secessionism, which implies full political and cultural dominance and an enlarged 
sphere of influence. Groups find an autonomy agreement inadequate and adhere to secession claims if they gain external diaspora support. Autonomy reforms provoke a desire for self-government among other groups. When the group achieved selfgovernment by force, other groups believe that this is a promising strategy (Toft, 2010; Walter, 2009; Wimmer, 2004). In this view, a 12) low degree of ethnic fractionalization is a favorable condition for autonomy success.

\section{Case selection and calibration}

A region is defined as TA, if it is a geographically defined area with a special status which was implemented after an ethnic conflict. This special status cannot be revoked unilaterally and includes exclusive legislative competences. For this study, all autonomies worldwide which currently exist in at least formal form are of interest. ${ }^{1}$ All relevant social groups which carry the attributes 'ethnic' as well as 'autonomous' are selected from the EPR dataset (Vogt et al., 2015). In a next step, it is examined whether those groups have been granted autonomy rights in the aftermath of ethnic conflict. This procedure reveals 19 TA worldwide which were implemented between 1922 and 2009 (Table 1). A conflict-regulating autonomy fulfils its intended function, if upcoming conflicts do not escalate, but are solved by peaceful means. Thus, a continued functioning is the most important criterion for success (OUT). The criterion is met when no violent conflict is reported in the settlement area for a period of at least two years. For operationalization, we use the Heidelberg conflict model, which allows to distinguish different conflict intensities and to classify them as being disputes, non-violent crises, violent crises, limited wars or wars (HIIK, 2016; Trinn \& Wencker, 2016). An autonomy system is seen as consolidated, if it has existed for a certain period of time and has, at best,

\footnotetext{
${ }^{1}$ Interim autonomies, historical cases and unilaterally declared autonomies are not being considered.
} 
survived several changes of government. The minimum time span is set at five years, which must have passed since the implementation. ${ }^{2}$ Since no conflict can be ended without the will of the conflict parties, autonomy consolidation requires fundamental acceptance. Ongoing secessionist movements indicate that the arrangement is not widely supported. Full success (Score $=1$ ) is achieved, if all three criteria are met unequivocally.

Figure 1: Operationalization and Calibration of autonomy success and failure.

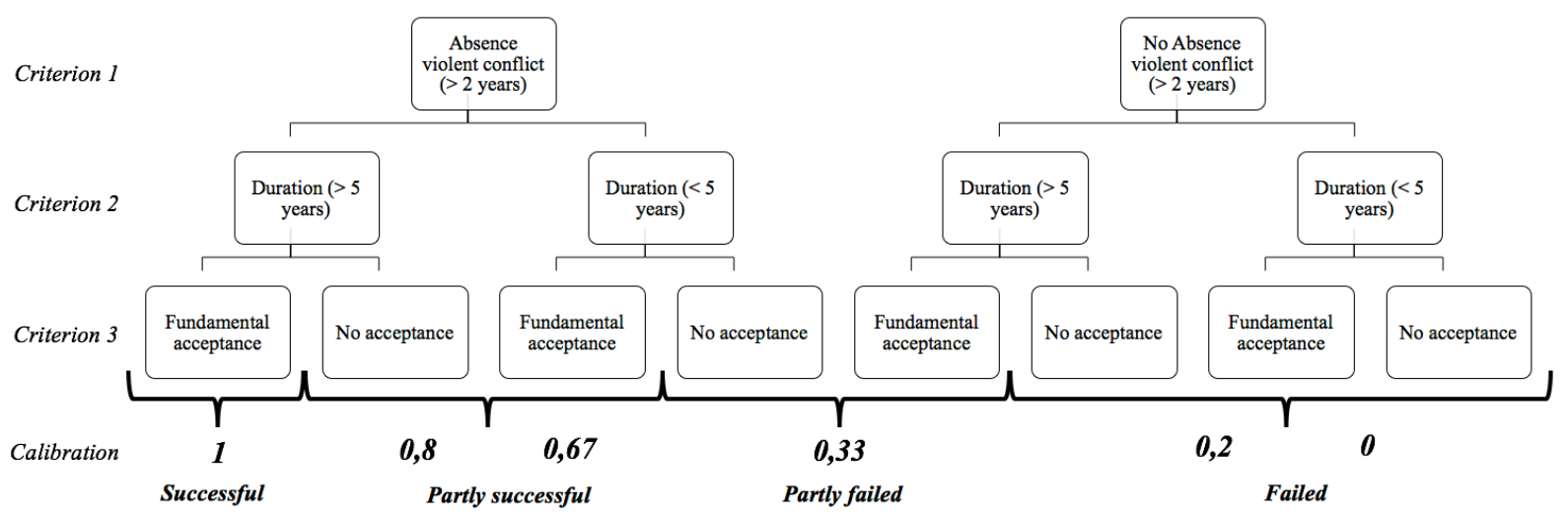

An autonomy arrangement is considered to be partially successful, if the conflict seems to be peacefully regulated, but one of the two other criteria is not or not fully met (Score $=0.8$ or 0.67 ). An autonomy arrangement is considered to be a partial failure when there is no violent conflict, but the autonomy shows neither a sufficient life span nor a basic acceptance, or the criteria of duration and acceptance are met, but there are still violent clashes between the conflict parties (Score $=$ 0.33). The prerequisite is then, however, that the conflict has not intensified. An autonomy is regarded as complete failure $($ Score $=0)$, if the conflict could not be ended or even has intensified. The two other criteria are of lesser importance in these cases. If one of those is met, the case is coded with 0.2 .

\footnotetext{
${ }^{2}$ Point of reference is December 2016.
} 
Table 1: Case selection

\begin{tabular}{|l|l|l|l|l|}
\hline Autonomy & Case & Conflict intensity & Outcome & Fuzzy Score \\
\hline Aceh & ACH & War & $\begin{array}{l}\text { Partly } \\
\text { successful }\end{array}$ & 0.67 \\
\hline Åland & ALA & Dispute & Successful & 1 \\
\hline $\begin{array}{l}\text { Atlantic Coast (RAAN/ } \\
\text { RAAS) }\end{array}$ & ATL & Violent Crisis & Failed & 0.2 \\
\hline Basque Country & BAS & Violent Crisis & $\begin{array}{l}\text { Partly } \\
\text { successful }\end{array}$ & 0.8 \\
\hline Bodoland & BOD & Limited War & Failed & 0.2 \\
\hline Bougainville & BOU & Limited War & $\begin{array}{l}\text { Partly } \\
\text { successful }\end{array}$ & 0.67 \\
\hline Catalonia & CAT & Dispute & $\begin{array}{l}\text { Partly } \\
\text { successful }\end{array}$ & 0.8 \\
\hline Chittagong Hill Tracts & CHT & Limited War & Failed & 0 \\
\hline Corsica & COR & Violent Crisis & $\begin{array}{l}\text { Partly } \\
\text { successful }\end{array}$ & 0.67 \\
\hline Gagauzia & GAG & Dispute & Successful & 1 \\
\hline Gilgit-Baltistan & GIL & Violent Crisis & Failed & 0 \\
\hline Guna Yala & GUN & Crisis & Successful & 1 \\
\hline Jammu Kashmir & JAM & War & Failed & 0 \\
\hline Kurdistan & KUR & War & Partly failed & 0.33 \\
\hline Muslim Mindanao & MIN & Limited War & Failed & 0 \\
\hline New Caledonia & CAL & Violent Crisis & Successful & 1 \\
\hline Northern Ireland & IRL & Limited War & Partly failed & 0.33 \\
\hline South Tyrol & TIR & Violent Crisis & Successful & 1 \\
\hline Zanzibar & SAN & Limited War & Partly failed & 0.33 \\
\hline
\end{tabular}

Whereas different measurement of decentralization (Lijphart, 1984; Hooghe et al., 2016; A. Schneider, 2003) omit the specifics of ethnic regionalization, the Autonomy Scope Index (ASI) provides information on the de facto degree of ethnic selfdetermination and is thus a suitable tool for the calibration of the condition 1) SCOPE (Schulte, 2018). 2) Horizontal inequalities exist when an ethnic groups is significantly better or worse off than other groups in the country for a longer period of time. The analysis focuses on the economic (ECONHU) and social inequality

${ }^{3}$ Highest Pre-conflict level on the territory before the autonomy implementation (HIIK, 2016). 
dimension (SOCHU). The economic dimension is measured with sub-state income and employment data. For the social dimension, access to health services, health status, as well as access to education and educational attainment levels is taken into account. Since cases in the sample range from welfare states to developing countries, fuzzy scores are calibrated qualitatively based on statistics from national or regional statistical offices or macro-quantitative indices, as well as survey data and NGO reports. 3) The condition DEMO is present, if the democratization of the central state begins shortly after the implementation without any democratic backsliding in the consolidation period. The condition is measured with the V-Dem Liberal Democracy Index (Teorell, Coppedge, Skaaning, \& Lindberg, 2016). A case is member of the set, if the values of the index increase continuously. Three time intervals $(5,15,30$ years) serve to determine the speed of democratization. With a value of $x>0.5$, a country is more democratic than autocratic. The existence of a 4) proportional voting system in the central state (PROP) is calibrated dichotomously using the Electoral System Design Database (IDEA, 2017). The degree of 5) decentralization (DECEN) is calibrated on basis of the Fiscal Decentralization Index (Ivanyna \& Shah, 2014). The condition 6) rule of law (RULE) is calibrated on the basis of the Rule of Law Index (World Justice Project, 2016). Cases are members of 7) ORGA, if an international or regional organization was involved in the peace process. Conciliations $($ Score $=0.6)$ and consultations $($ Score $=0.7)$ are the weakest forms of international engagement (Fisher, 2011). Mediations (Score $=0.8$ ) imply a more active role of a third party. While international mediation is about finding an interest-based compromise, arbitration (Score 0.9) results in a binding judgment. The highest level of intervention is peacekeeping $($ Score $=1$ ), in which the third party provides military personnel in order to monitor an agreement. Four criteria are set to calibrate 8) international integration (INTEG): a) the duration until the first admission. According to the 
theoretical assumptions, a fast integration is an advantage. It matters b) if the autonomous government has observer status or is a full member. The c) higher the number of memberships in total, the stronger is the international integration. Particularly important are c) parallel memberships, i.e. the central state is a member in the same organization as the regional government. The condition 9) STRAGY is based on the conflict intensity (HIIK, 2016) and the type of demands. The distinction between autonomy and secession claims is made on the basis of statements by group elites or rebel groups fighting on behalf of the group. The condition 10) NATIO is present when one or more nationalist parties have governed or participated in a governing coalition in the central state over the past 20 years. The dichotomous condition is calibrated using the Political Institutions dataset (Cruz, Keefer, \& Scartascini, 2016). The condition 11) TEK describes whether a

group has one or more diasporic groups. It is calibrated using the Transborder Ethnic Kin data set (Vogt et al., 2015). The condition of an 12) homogeneous central state (HOMOG) is calibrated indirectly on basis of different data sources (Birnir et al., 2018; CIA, 2017; Girardin, Hunziker, Cederman, Bormann, \& Vogt, 2015; Levinson, 1998).

\section{Configurational analysis of success and failure}

QCA is a powerful tool for detecting complex causality structures and is suitable for discovering relevant conditions or combinations of conditions for autonomy success and failure. To address the fundamental problem of too few cases and too many independent variables, a two-step procedure is carried out. In a first step, all selected conditions are combined into three different models: A comprehensive model, including the conditions STRAGY, SCOPE, ECONHU, SOCHU, DEMO, ORGA, INTEG, an institutional model (PROP, DECEN, RULE) and an actorcentered model (NATIO, TEK and HOMOG). In a second step, only empirically relevant factors are summarized to higher-order concepts and combined into two 
empirical models (Ragin, 2000). In this way, both a high degree of intension and extension can be achieved. First, all conditions and their complements are tested whether they are necessary for autonomy success OUT. The minimum consistency level is set at 0.9. To sort out trivial conditions, only conditions are selected which have a coverage of 0.65 or higher (C. Q. Schneider \& Wagemann, 2012). In order to test for sufficiency, a truth table is build, which consists of all logically possible configurations of conditions. The threshold value for consistency is set at 0.75 as the conventional benchmark (Thomann \& Maggetti, 2017).

\section{Comprehensive Model}

In the comprehensive model, no condition alone is necessary for success. However, the conditions show the predicted causal direction: A high degree of autonomy, a peaceful group strategy, democracy and international integration have a positive effect if the condition is present. ${ }^{4}$ Conversely, the absence of the two inequality conditions has a positive effect. The logical minimization of the truth table yields the following solution term: SCOPE* DEMO*INTEG (consistency 0.891 and coverage 0.575). ${ }^{5}$ The result unravels the basic cornerstones of successful selfgovernment: a high degree of transferred competences, the implementation in a democratic or rapidly democratizing central state, and the international integration of autonomy. ${ }^{6}$ In other words: internal recognition (SCOPE), external recognition

${ }^{4}$ Uppercase letters indicating the presence of a certain condition, and lowercase letters (or ) indicating its absence. The signs ' + ' stands for the logical OR whereas the '*, stands for the logical AND. All analyses were conducted using $\mathrm{R}$ with the packages QCA, SetMethods and QCAtools (Dusa, 2018).

${ }^{5}$ The intermediate solution is used here. Logical remainders are treated based on theoretical assumptions. The parsimonious solution and the conservative solution provide a too complex solution that provides little information.

${ }^{6}$ Since the explanation of (completely) successful autonomies is of primary importance, only the first two rows of the truth table are considered for the intermediate solution. A consideration of the first 6 rows leads to the following solution terms: 
(INTEG) and a regime that does not oppose cultural diversity (DEMO), enable ethnic self-government and peaceful conflict settlement. According to the hypotheses, the absence of the conditions STRAGY, SCOPE, DEMO, ORGA and INTEG and the presence of the conditions ECONHU and SOCHU should lead to a autonomy failure (out or $\sim$ OUT). The analysis of all necessary conditions with a coverage of at least 0.65 mirrors the conversed conditions of the success formula: scope+demo+integ (consistency 0.922 and coverage 0.661). Both the conservative solution and the intermediate solution contain five different solution terms. High conflict intensity and persistent inequalities make autonomies fail if international support is missing. The cases CHT, KUR, GIL and MIN were implemented also in non-democratic surroundings and have received a comparatively low degree of autonomy.

Table 2: Conservative Solution for failed autonomies (Consistency $=0.919$ and Coverage $=$ $0.546)$.

\begin{tabular}{|l|l|l|l|}
\hline & Consistency & Coverage & Cases \\
\hline stragy*scope*ECONHU*demo*orga*integ & 0.896 & 0.287 & $\begin{array}{l}\text { GIL, } \\
\text { CHT }\end{array}$ \\
\hline stragy*scope*ECONHU*SOCHU*demo*integ & 0.909 & 0.331 & $\begin{array}{l}\text { CHT, } \\
\text { MIN }\end{array}$ \\
\hline stragy*scope*ECONHU*SOCHU*orga*integ & 0.872 & 0.302 & $\begin{array}{l}\text { CHT, } \\
\text { BOD } \\
\text { JAM }\end{array}$ \\
\hline stragy*SCOPE*ECONHU*'sochu*DEMO*ORGA*INTEG & 0.967 & 0.097 & IRL \\
\hline stragy*SCOPE*ECONHU*SOCHU*demo*orga*INTEG & 1.000 & 0.141 & KUR \\
\hline
\end{tabular}

\section{Institutional Model}

The successful cases exist in central states with an proportional electoral system or a highly decentralized state structure $(P R O P+D E C E N$ with consistency 0.910 and

SCOPE*DEMO*orga*INTEG + SCOPE*econhu* ${ }^{*}$ sochu*ORGA + sochu*DEMO*orga*INTEG + SCOPE* ${ }^{*}$ sochu*demo*ORGA*INTEG $\rightarrow$ OUT (consistency $=0.921$; coverage $=0,628)$ and explains additionally the cases CAT (Term 1), COR, CAT (Term 2) and ACH (Term 4). 
coverage 0.660$)$. The analysis of sufficient conditions with a minimum consistency of 0.75 yields the following conservative and intermediate solution: $R U L E^{*} D E C E N^{*} P R O P$ (consistency 0.787 and coverage 0.369). For autonomy failure, using a consistency threshold of 0.9 and a coverage value of 0.65 , no necessary condition can be detected. The absence of PROP is found as an sufficient condition (prop with consistency 0.644 and coverage 0.649 ).

\section{Actor-centered Model}

Using the same consistency values, neither NATIO nor TEK are a necessary condition in presence or absence for autonomy success. However, they are in combination in their absence sufficient conditions. Since nationalist parties seems to be decisive mediating variable, the condition is integrated into the holistic model. HOMOG is neither a necessary nor a sufficient condition and is disregarded. The analysis with $\sim$ OUT shows no necessity of the three conditions. The two solution terms NATIO*homog (consistency 0.941 and coverage 0.237 ) and natio ${ }^{*}$ TEK ${ }^{*} H O M O G$ (consistency 0.802 and coverage 0.207 ) do not produce unequivocal evidence. The conditions are therefore not integrated into the overall model of autonomy failure.

\section{Empirical models}

All three models offer causally relevant conditions for autonomy consolidation. In the first model, a high degree of autonomy, democracy, the international component and the absence of inequalities are empirically relevant. In the second model, the rule of law, decentralisation and proportional representation are relevant. In the third model, the absence of nationalist parties and diaspora groups are significant. For the failure of autonomy, almost without exception the complements of the conditions of success are relevant. This finding confirms the importance of the factors identified for institutional conflict regulation. 
Table 3: Empirically relevant conditions

\begin{tabular}{|l|l|l|}
\hline & Success & Failure \\
\hline $\begin{array}{l}\text { Model } \\
\text { A }\end{array}$ & $\begin{array}{l}\text { SCOPE, DEMO, ORGA/INTEG, } \\
\text { (econhu, sochu })\end{array}$ & $\begin{array}{l}\text { ECONHU, SOCHU, stragy, scope, demo, } \\
\text { orga/integ }\end{array}$ \\
\hline $\begin{array}{l}\text { Model } \\
\text { B }\end{array}$ & RULE, DECEN, PROP & prop \\
\hline $\begin{array}{l}\text { Model } \\
\text { C }\end{array}$ & natio, tek & NATIO \\
\hline
\end{tabular}

Since these are still too many conditions for a further QCA analysis, the empirically relevant conditions are now summarized to higher-order concepts. Rule of law is an undeniable component of liberal democracy. The conditions DEMO and RULE are therefore logically added to a condition 'democratic constitutional state' (DEMOCR). A case is member of DEMOCR, if the central state is both a democracy and a constitutional state. INTEG and ORGA are based on the theoretical argument that there must be external support as well as negotiation opportunities at the international level. Both conditions are summarized to the condition INTERN. The condition describes the internationalization of the autonomy arrangement, whether through the involvement of international organizations in the implementation process or through international integration. The conditions are linked by a logical OR. According to the maximum rule, the highest fuzzy value of INTEG or ORGA gives the fuzzy value for INTERN (C. Q. Schneider \& Wagemann, 2012). The two inequality conditions ECONHU and SOCHU are connected in the same way and form the condition INEQU. Both factors are based on the same theoretical argument and are strongly interdepend. The condition INEQU describes whether strong economic or social inequalities exist between the ethnic groups. The highest fuzzy score of the two original conditions gives the fuzzy value of the higher order concept. The conditions PROP and DECEN can be summarized on the basis of the theoretical considerations to a condition of 'inclusive state organizations' (INCL). However, as it is very common in the sample that a case has a proportional representation or a decentralized state 
structure, the condition becomes trivial. As an proxy for inclusive state organizations, therefore, the condition PROP is used. The conditions SCOPE, STRAGY and NATIO cannot be combined logically. Based on the empirical results, it is assumed that a combination of low inequalities, a high degree of autonomy, democracy, inclusive institutions, minority-friendly parties and internationalisation leads to autonomy consolidation. On the other hand, strong inequalities and a previous violent conflict as well as a low degree of autonomy and exclusive institutions at the state level should lead to a failure of post-conflict autonomy reforms.

Figure 2: Empirical Model of Autonomy Success.

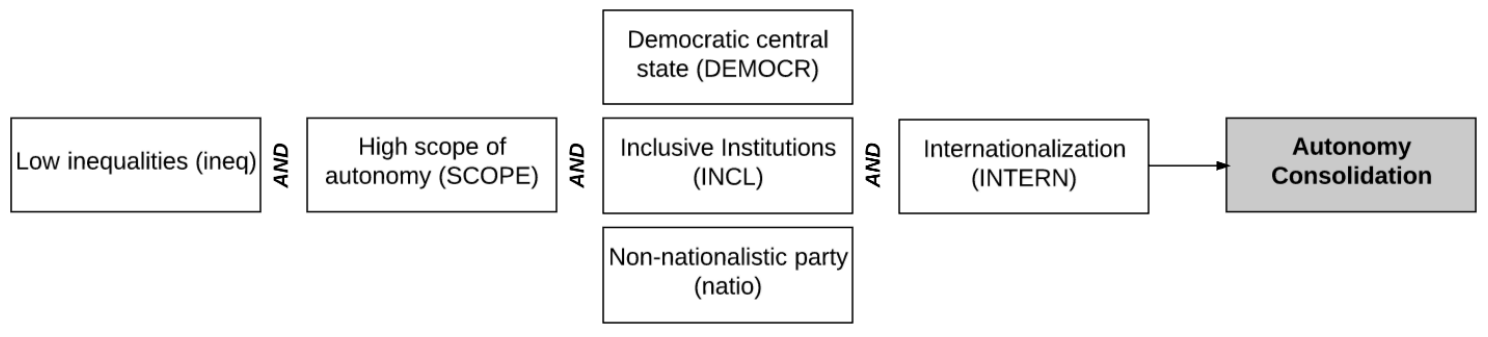

Figure 3: Empirical Model of Autonomy Failure.

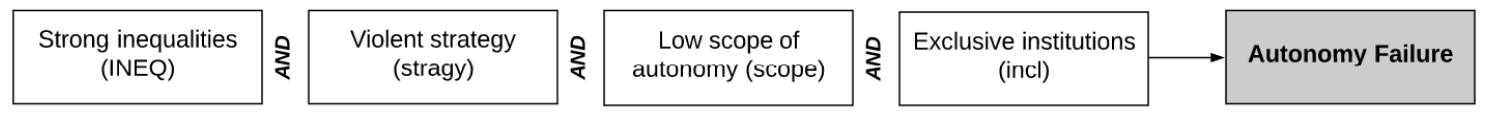

The sufficiency test confirms the theoretical assumptions. The logical minimization of the truth table (intermediate and conservative solution) leads to the following solution terms: SCOPE*DEMOCR*INCL ${ }^{*}$ natio*INTERN $\rightarrow$ OUT (with consistency 0.842 and coverage 0.670 representing the cases ALA, GAG, TIR, ACH, BAS, CAT and CAL) and inequ*SCOPE*DEMOCR*INCL ${ }^{*}$ natio ${ }^{*} I N T E R N \rightarrow$ OUT (with consistency 0.910 and coverage 0.302 representing the cases ALA, GAG, TIR). Both formula contain the relevant conditions with the predicted 'sign'. Weak horizontal inequalities seem to have a positive effect, as the European model cases ALA, GAG and TIR show. The first solution formula indicates that negative 
effects can obviously be adequately compensated by the presence of the other success factors.

The analysis of sufficient conditions for autonomy failure also confirms the assumptions of the model (conservative and intermediate solution): INEQU ${ }^{*}$ stragy*scope ${ }^{*}$ incl $\rightarrow$ out (with consistency 0.905 and coverage 0.464 representing the cases BOD, CHT, GIL, JAM, COR and MIN). ${ }^{7}$ Inequalities, a strategy of violence, a low degree of autonomy and non-inclusive institutions caused autonomy reforms in India, Bangladesh or Pakistan to fail completely or partially.

\section{Conclusion}

Ethnic peace is not the result of an 'invisible hand', but of an emerging regime of accommodative institutions (Cederman \& Vogt, 2017; Gurr, 2000). Institutions can transform ethnic self-determination conflicts into peaceful coexistence. Research has already developed an extensive 'menu of institutional engineering' and finds some empirical evidence for peace-promoting effects of specific institutions (Ansorg \& Kurtenbach, 2017). TA is not a relevant option for alleviating tensions between ethnic groups in all contexts. It is neither a panacea, nor has it a 'terrible track record' (Snyder, 2000, p. 327). Contrary to the arguments of critics, a majority of conflict-regulating TAs implemented since 1945 have suffered neither recentralization nor secession. Where autonomy reforms have been implemented as part of a peace treaty to end ethnic conflict, most have succeeded in at least reducing violence to manageable levels. The evidence presented here suggests that the variation in outcomes is attributable to favourable and

\footnotetext{
${ }^{7}$ The factors NATIO, intern and democr that seem to play a decisive role, but which
} causal role could not be finally confirmed, are excluded. The conservative solution with DECEN instead of PROP for INCL confirms the results. The (conservative) solution formula is: INEQU* ${ }^{*}$ stragy* ${ }^{*}$ scope* $^{*}$ decen $\rightarrow$ out with consistency $=0.902$ and coverage $=0.479$ and the cases BOD, CHT, GIL, JAM and MIN. 
unfavourable framework conditions. The effectiveness of institutional reforms to regulate ethnic conflicts is highly context-sensitive. This article argued that the core of ethnic conflicts lies in the non-recognition of ethnic identity. Institutional measures must ensure recognition through empowerment or inclusion. Mutual recognition succeeds under some circumstances and fails under others. The results of the configurational analysis show that a combination of six conditions create a fruitful basis: Low inequality between ethnic groups, a high degree of autonomy, a democratizing central state with inclusive institutions, the participation of minority-friendly parties in the consolidation phase as well as support by international organizations or the international integration of autonomy. Autonomies fail when inequalities between groups are strong, the previous conflict was highly violent, only inadequate competencies were transferred and the group remains politically excluded. Research questions in this direction are not only a promising development from a scientific point of view. They also have a high practical benefit. Some of the conditions identified, such as a high degree of autonomy, inclusive institutions and international support, are changeable factors in peace processes that increase the chances of ethnic peace. 


\section{References}

Ansorg, N., \& Kurtenbach, S. (Eds.). (2017). Institutional reforms and peacebuilding: change, path-dependency and societal divisions in post-war communities. London; New York: Routledge, Taylor \& Francis Group.

Bakke, K. M. (2015). Decentralization and intrastate struggles: Chechnya, Punjab, and Québec. New York: Cambridge University Press.

Birnir, J. K., Laitin, D. D., Wilkenfeld, J., Waguespack, D. M., Hultquist, A. S., \& Gurr, T. R. (2018). Introducing the AMAR (All Minorities at Risk) Data. Journal of Conflict Resolution, 62(1), 203-226. https://doi.org/10.1177/0022002717719974

Burton, J. W. (1997). Violence Explained: The Sources of Conflict, Violence and Crime and Their Prevention. Manchester: Manchester University Press.

Caporaso, J. (1992). International Relations Theory and Multilateralism. The Search for Foundations. International Organization, 46, 599-632.

Cederman, L.-E., Gleditsch, K. S., \& Buhaug, H. (2013). Inequality, Grievances, and Civil War. Cambridge: Cambridge University Press.

Cederman, L.-E., Gleditsch, K. S., \& Wucherpfennig, J. (2017). The Diffusion of Inclusion: An Open-Polity Model of Ethnic Power Sharing. Comparative Political Studies, 001041401774060. https://doi.org/10.1177/0010414017740602

Cederman, L.-E., Hug, S., \& Wucherpfennig, J. (2015). Autonomy, Secession and Conflict: A Strategic Model. Presented at the ENCoReConference Barcelona, Barcelona.

Cederman, L.-E., \& Vogt, M. (2017). Dynamics and Logics of Civil War. Journal of Conflict Resolution, 61(9), 1992-2016.

https://doi.org/10.1177/0022002717721385

Chapman, T., \& Roeder, P. G. (2007). Partition as a Solution to Wars of Nationalism: The Importance of Institutions. American Political Science Review, 101(4). https://doi.org/10.1017/S0003055407070438

CIA. (2017). The World Factbook - Central Intelligence Agency. Retrieved 5 October 2017, from https://www.cia.gov/library/publications/the-worldfactbook/

Cruz, C., Keefer, P., \& Scartascini, C. (2016). The Database of Political Institutions 2015 (DPI2015). Retrieved from http://publications.iadb.org/handle/11319/7408 
Dusa, A. (2018). R Package QCA (Version 3.1).

Fisher, R. J. (2011). Methods of Third-Party Intervention. In B. Austin, M. Fischer, \& H.-J. Giessmann (Eds.), Advancing Conflict Transformation. The Berghof Handbook II. Opladen.

Ghai, Y. (2000). Autonomy and Ethnicity. Negotiating Competing Claims in Multi-ethnic states. Cambridge.

Gherghina, S. (2009). The success of extremist parties in Central and Eastern European States and its causes. In U. Backes, T. Jaskulowski, \& A. Polese (Eds.), Totalitarismus und Transformation (pp. 185-208). Göttingen: Vandenhoeck and Ruprecht.

Gherghina, S., \& Jiglău, G. (2016). Playing Their Cards Right: Ethnic Parties and Government Coalitions in Postcommunist Europe. Nationalism and Ethnic Politics, 22(2), 220-240. https://doi.org/10.1080/13537113.2016.1169065

Girardin, L., Hunziker, P., Cederman, L.-E., Bormann, N.-C., \& Vogt, M. (2015). GROWup - Geographical Research On War, Unified Platform. ETH Zurich. Retrieved 29 June 2016, from http://growup.ethz.ch/

Gurr, T. R. (1970). Why Men rebel. Princeton.

Gurr, T. R. (1993). Minorities at risk: a global view of ethnopolitical conflicts. Washington, D.C: United States Institute of Peace Press.

Gurr, T. R. (2000). Peoples versus states: Minorities at risk in the new century. Washington, D.C.: United States Institute of Peace Press.

Gurses, M. (2015). Transnational Ethnic Kin and Civil War Outcomes. Political Research Quarterly, 68(1), 142-153.

Henderson, A., \& McEwen, N. (2010). A comparative analysis of voter turnout in regional elections. Electoral Studies, 29(3), 405-416.

https://doi.org/10.1016/j.electstud.2010.03.012

HIIK. (2016). Heidelberg Institute for International Conflict Research. Retrieved from http://www.hiik.de/de/daten/index.html

Hooghe, L., Schakel, A. H., Marks, G., Niedzwiecki, S., Osterkatz, S. C., \& ShairRosenfield, S. (2016). Measuring regional authority: a postfunctionalist theory of governance. Volume I. Oxford, United Kingdom; New York: Oxford University Press.

Horowitz, D. L. (1985). Ethnic Groups in Conflict. Los Angeles.

Hultman, L., Kathman, J., \& Shannon, M. (2013). United Nations Peacekeeping and Civilian Protection in Civil War. American Journal of Political 
Science, n/a-n/a. https://doi.org/10.1111/ajps.12036

IDEA. (2017). IDEA. Electoral System Design Database. Retrieved from www.idea.int

Ivanyna, M., \& Shah, A. (2014). How Close Is Your Government to Its People? Worldwide Indicators on Localization and Decentralization. Economics: The Open-Access, Open-Assessment E-Journal, 8(2014-3), 1. https://doi.org/10.5018/economics-ejournal.ja.2014-3

Kapur, D. (2010). Diaspora, Development, and Democracy: The Domestic Impact of International Migration from India. Princeton University Press.

Kelman, H. C. (2007). Social-psychological dimensions of international conflict. In W. Zartman (Ed.), Peacemaking in international conflict (pp. 61-107). Washington, DC: U.S. Institute of Peace.

King, E., \& Samii, C. (2017). Minorities and mistrust: On the adoption of ethnic recognition to manage conflict. Journal of Peace Research. https://doi.org/10.1177/0022343317707803

Levinson, D. (1998). Ethnic groups worldwide: A ready reference handbook. Phoenix, Ariz.: Oryx Press.

Lijphart, A. (1968). The Politics of Accomodation. Pluralism and Democracy in the Netherlands. Berkeley-Los Angeles.

Lijphart, A. (1984). Democracies. Patterns of Majoritarian and Consensus Government in Twenty-one Countries. New Haven-London.

Malloy, T. H. (2013). Minority Issues in Europe: Rights, Concepts, Policy. Frank \& Timme GmbH.

May, S., Modood, T., \& Squires, J. (2004). Ethnicity, Nationalism, and Minority Rights. Cambridge University Press.

McGarry, J., \& O’Leary, B. (1993). The Politics of Ethnic Conflict Regulation. Case studies of protracted ethnic conflicts. New York.

Meadwell, H. (2009). The Political Dynamics of Secession and Institutional Accommodation. Regional \& Federal Studies, 19(2), 221-235. https://doi.org/10.1080/13597560902753446

Papagianni, K. (2009). Political Transitions after Peace Agreements: The Importance of Consultative and Inclusive Political Processes. Journal of Intervention and Statebuilding, 3(1), 47-63. https://doi.org/10.1080/17502970802608175

Ragin, C. C. (2000). Fuzzy-Set Social Science. University of Chicago Press. Russett, B., \& Oneal, J. R. (2001). Triangulating Peace. Democracy, 
Interdependence, and International Organizations. London.

Sambanis, N., Germann, M., \& Schädel, A. (2017). SDM: A New Data Set on Self-determination Movements with an Application to the Reputational Theory of Conflict. Journal of Conflict Resolution, 62(3), 0022002717735364. https://doi.org/10.1177/0022002717735364

Schneider, A. (2003). Decentralization. Conceptualization and Measurement. Studies in Comparative International Development, 38(3), 32-56.

Schneider, C. Q., \& Wagemann, C. (2012). Set-theoretic methods for the social sciences: a guide to qualitative comparative analysis. Cambridge: Cambridge University Press.

Schulte, F. (2018). The More, The Better? Assessing the Scope of Regional Autonomy as a Key Condition for Ethnic Conflict Regulation. International Journal on Minority and Group Rights, 25(1). https://doi.org/10.1163/15718115-02511084

Snyder, J. L. (2000). From voting to violence: democratization and nationalist conflict. New York, NY: Norton.

Stewart, F. (2008). Horizontal Inequalities and Conflict. Understanding Group Violence in Multiethnic Societies. London.

Tajfel, H., \& Turner, J. C. (1979). An integrative theory of intergroup conflict. In W. G. Austin \& S. Worchel (Eds.), The social psychology of intergroup relations (pp. 33-47). Monterey.

Teorell, J., Coppedge, M., Skaaning, S.-E., \& Lindberg, S. I. (2016). Measuring Electoral Democracy with V-Dem Data: Introducing a New Polyarchy Index. V-Dem Working Paper, (25).

Thomann, E., \& Maggetti, M. (2017). Designing Research with Qualitative Comparative Analysis (QCA): Approaches, Challenges, and Tools. Sociological Methods $\mathscr{G}$ Research.

Toft, M. D. (2010). The Geography of Ethnic Violence: Identity, Interests, and the Indivisibility of Territory. Princeton: Princeton University Press. Retrieved from http://public.eblib.com/choice/publicfullrecord.aspx?p=485804

Tranchant, J.-P. (2016). Is Regional Autonomy a Solution to Ethnic Conflict? Some Lessons from a Dynamic Analysis. Peace Economics, Peace Science and Public Policy, 22(4). https://doi.org/10.1515/peps-2016-0028

Trinn, C., \& Wencker, T. (2016). Introducing the Heidelberg approach to conflict research. European Political Science. https://doi.org/10.1057/s41304-0160093-4 
Vogt, M., Bormann, N.-C., Ruegger, S., Cederman, L.-E., Hunziker, P., \& Girardin, L. (2015). Integrating Data on Ethnicity, Geography, and Conflict: The Ethnic Power Relations Data Set Family. Journal of Conflict Resolution, 59(7), 1327-1342. https://doi.org/10.1177/0022002715591215

Walsh, D. (2018). Territorial Self-Government as a Conflict Management Tool. Cham: Springer International Publishing. https://doi.org/10.1007/978-3319-77234-9

Walter, B. F. (2009). Reputation and civil war: why separatist conflicts are so violent. Cambridge: Cambridge Univ. Press.

Wimmer, A. (Ed.). (2004). Facing ethnic conflicts: toward a new realism. Lanham, MD: Rowman \& Littlefield.

Wimmer, A. (2013). Waves of War. Nationalism, State Formation, and Ethnic Exclusion in the Modern World. Cambridge.

Wolff, S. (2013). Conflict Management in Divided Societies: The Many Uses of Territorial Self-Governance. International Journal on Minority and Group Rights, 20(1), 27-50. https://doi.org/10.1163/15718115-02001003

World Justice Project. (2016). WJP Rule of Law Index 2016 | The World Justice Project. Retrieved 30 November 2016, from http://worldjusticeproject.org/rule-of-law-index

Zürcher, C. (Ed.). (2013). Costly democracy: peacebuilding and democratization after war. Stanford, Calif: Stanford Univ. Press. 


\section{Appendix}

Table 4: Data matrix

\begin{tabular}{|c|c|c|c|c|c|c|c|c|}
\hline & STRAGY & SCOPE & ECONHU & SOCHU & DEMO & ORGA & INTEG & OUT \\
\hline $\mathrm{ACH}$ & 0 & 0.75 & 1 & 0.2 & 0.67 & 0.8 & 0.6 & 0.67 \\
\hline ALA & 0.9 & 0.97 & 0 & 0 & 0.9 & 0.9 & 0.9 & 1 \\
\hline ATL & 0.7 & 0.47 & 1 & 1 & 0.45 & 0.6 & 0 & 0.2 \\
\hline BAS & 0.4 & 0.92 & 0.7 & 0.7 & 0.88 & 0 & 1 & 0.8 \\
\hline BOD & 0.2 & 0.36 & 1 & 1 & 0.69 & 0 & 0 & 0.2 \\
\hline $\mathrm{BOU}$ & 0.2 & 0.67 & 0.2 & 0 & 0.43 & 1 & 0.1 & 0.67 \\
\hline CAL & 0.4 & 0.83 & 1 & 1 & 0.95 & 0 & 0.9 & 1 \\
\hline CAT & 0.8 & 0.92 & 0.6 & 0.3 & 0.88 & 0 & 1 & 0.8 \\
\hline $\mathrm{CHT}$ & 0.1 & 0.17 & 1 & 1 & 0.43 & 0.1 & 0.4 & 0 \\
\hline COR & 0.4 & 0.25 & 0.6 & 0 & 0.95 & 0 & 0.9 & 0.67 \\
\hline GAG & 0.7 & 0.69 & 0 & 0 & 0.67 & 0.6 & 0.6 & 1 \\
\hline GIL & 0.3 & 0.36 & 0.7 & 0.3 & 0.41 & 0 & 0.4 & 0 \\
\hline GUN & 0.7 & 0.47 & 0.7 & 0.8 & 0.77 & 0.6 & 0 & 1 \\
\hline IRL & 0.2 & 0.72 & 0.7 & 0 & 0.96 & 0.8 & 0.9 & 0.33 \\
\hline $\mathrm{JAM}$ & 0 & 0.28 & 0.7 & 0.6 & 0.69 & 0.3 & 0 & 0 \\
\hline KUR & 0 & 0.92 & 1 & 0.8 & 0.4 & 0 & 0.6 & 0.33 \\
\hline MIN & 0.2 & 0.17 & 1 & 1 & 0.6 & 1 & 0.3 & 0 \\
\hline SAN & 0.2 & 0.64 & 0 & 0 & 0.4 & 0 & 0.8 & 0.33 \\
\hline TIR & 0.6 & 0.86 & 0 & 0 & 0.87 & 0.7 & 1 & 1 \\
\hline
\end{tabular}

Table 5: Truth table for OUT

\begin{tabular}{|c|c|c|c|c|c|c|c|c|c|c|c|}
\hline & 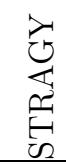 & 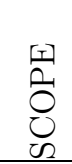 & 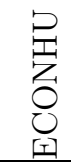 & $\begin{array}{l}\sqsupseteq \\
己 \\
\circlearrowright \\
\circlearrowright\end{array}$ & $\underset{\substack{\text { I } \\
\text { 至 }}}{0}$ & $\begin{array}{l}\underset{J}{J} \\
\underset{0}{0}\end{array}$ & $\begin{array}{l}\text { 己 } \\
\text { 点 } \\
\text { 点 }\end{array}$ & $\stackrel{5}{5}$ & $\mathrm{~N}$ & Consistency & Cases \\
\hline 1 & 1 & 1 & 0 & 0 & 1 & 1 & 1 & 1 & 3 & 1.0 & ALA, GAG, TIR \\
\hline
\end{tabular}




\begin{tabular}{|l|l|l|l|l|l|l|l|l|l|l|l|}
\hline 2 & 0 & 1 & 1 & 1 & 1 & 0 & 1 & 1 & 2 & 1.0 & BAS, CAL \\
\hline 3 & 0 & 0 & 1 & 0 & 1 & 0 & 1 & 1 & 1 & 1.0 & COR \\
\hline 4 & 0 & 1 & 1 & 0 & 0 & 1 & 1 & 1 & 1 & 1.0 & ACH \\
\hline 5 & 1 & 1 & 1 & 0 & 1 & 0 & 1 & 1 & 1 & 1.0 & CAT \\
\hline 6 & 0 & 1 & 0 & 0 & 0 & 1 & 0 & 1 & 1 & 0.819 & BOU \\
\hline 7 & 0 & 1 & 1 & 0 & 1 & 1 & 1 & 0 & 1 & 0.589 & IRL \\
\hline 8 & 0 & 1 & 0 & 0 & 0 & 0 & 1 & 0 & 0 & 0.562 & SAN \\
\hline 9 & 1 & 0 & 1 & 1 & 0 & 1 & 0 & 0 & 2 & 0.537 & ATL, GUN \\
\hline 10 & 0 & 0 & 1 & 1 & 1 & 0 & 0 & 0 & 2 & 0.500 & BOD, JAM \\
\hline 11 & 0 & 1 & 1 & 1 & 0 & 0 & 1 & 0 & 1 & 0.417 & KUR \\
\hline 12 & 0 & 0 & 1 & 1 & 0 & 0 & 0 & 0 & 1 & 0.380 & CHT \\
\hline 13 & 0 & 0 & 1 & 1 & 0 & 1 & 0 & 0 & 1 & 0.368 & MIN \\
\hline 14 & 0 & 0 & 1 & 0 & 0 & 0 & 0 & 0 & 1 & 0.324 & GIL \\
\hline
\end{tabular}

Table 6: Truth table for out

\begin{tabular}{|c|c|c|c|c|c|c|c|c|c|c|c|c|}
\hline & 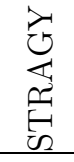 & \begin{tabular}{l}
1 \\
\multirow{1}{1}{} \\
0 \\
0 \\
0 \\
\hdashline
\end{tabular} & 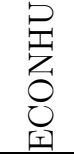 & $\begin{array}{l}\text { 忌 } \\
\text { O } \\
\text { O }\end{array}$ & 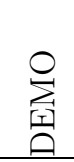 & 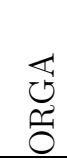 & $\begin{array}{l}\text { U } \\
\text { 空 } \\
\text { 至 }\end{array}$ & $\vec{z}$ & $\mathrm{~N}$ & Consistency & PRI & Cases \\
\hline 1 & 0 & 1 & 1 & 1 & 0 & 0 & 1 & 1 & 1 & 1.000 & 1.000 & KUR \\
\hline 2 & 0 & 1 & 1 & 0 & 1 & 1 & 1 & 1 & 1 & 0.967 & 0.919 & IRL \\
\hline 3 & 0 & 0 & 1 & 1 & 0 & 0 & 0 & 1 & 1 & 0.884 & 0.842 & CHT \\
\hline 4 & 0 & 0 & 1 & 0 & 0 & 0 & 0 & 1 & 1 & 0.865 & 0.833 & GIL \\
\hline 5 & 0 & 0 & 1 & 1 & 0 & 1 & 0 & 1 & 1 & 0.842 & 0.800 & MIN \\
\hline 6 & 0 & 0 & 1 & 1 & 1 & 0 & 0 & 1 & 2 & 0.800 & 0.714 & BOD, JAM \\
\hline 7 & 0 & 0 & 1 & 0 & 1 & 0 & 1 & 0 & 1 & 0.767 & 0.000 & $\mathrm{COR}$ \\
\hline 8 & 0 & 1 & 0 & 0 & 0 & 0 & 1 & 0 & 1 & 0.692 & 0.588 & SAN \\
\hline 9 & 1 & 1 & 1 & 0 & 1 & 0 & 1 & 0 & 1 & 0.630 & 0.000 & CAT \\
\hline 10 & 0 & 1 & 1 & 0 & 0 & 1 & 1 & 0 & 1 & 0.614 & 0.000 & $\mathrm{ACH}$ \\
\hline 11 & 1 & 0 & 1 & 1 & 0 & 1 & 0 & 0 & 2 & 0.610 & 0.543 & ATL, GUN \\
\hline 12 & 0 & 1 & 0 & 0 & 0 & 1 & 0 & 0 & 1 & 0.394 & 0.230 & $\mathrm{BOU}$ \\
\hline 13 & 0 & 1 & 1 & 1 & 1 & 0 & 1 & 0 & 2 & 0.375 & 0.000 & BAS, KAL \\
\hline 14 & 1 & 1 & 0 & 0 & 1 & 1 & 1 & 0 & 3 & 0.093 & 0.000 & ALA, GAG, TIR \\
\hline
\end{tabular}

Table 7: Conservative Solution for Successful autonomies

\begin{tabular}{|l|l|l|l|}
\hline & Consistency & Coverage & Cases \\
\hline stragy*scope*ECONHU* ${ }^{*}$ sochu*DEMO*orga*INTEG & 1.000 & 0.116 & COR \\
\hline stragy*SCOPE*econhu*sochu*demo*ORGA*integ & 0.819 & 0.127 & BOU \\
\hline stragy*SCOPE*ECONHU* sochu*demo*ORGA*INTEG & 1.000 & 0.070 & ACH \\
\hline
\end{tabular}




\begin{tabular}{|l|l|l|l|}
\hline stragy*SCOPE*ECONHU*SOCHU*DEMO*orga*INTEG & 1.000 & 0.160 & BAS, \\
\hline STRAGY*SCOPE*econhu*sochu*DEMO*ORGA*INTEG & 1.000 & 0.215 & ALA, \\
& & & GAG, \\
\hline STRAGY*SCOPE*ECONHU* ${ }^{*}$ sochu*DEMO*orga*INTEG & 1.000 & 0.135 & CAT \\
\hline
\end{tabular}

Table 8: Intermediate Solution for successful autonomies.

\begin{tabular}{|l|l|l|l|}
\hline & Consistency & Coverage & Cases \\
\hline SCOPE*DEMO*INTEG & 0.891 & 0.575 & BAS, CAL, ALA, GAG, TIR \\
\hline
\end{tabular}

Table 9: Test for necessary conditions for failed autonomies.

\begin{tabular}{|l|l|l|l|}
\hline & Consistency & RoN & Coverage \\
\hline scope+demo+integ & 0.922 & 0.603 & 0.661 \\
\hline
\end{tabular}

Table 10: Conservative Solution for failed autonomies (Consistency $=0.919$ and Coverage $=$ $0.546)$.

\begin{tabular}{|l|l|l|l|}
\hline & Consistency & Coverage & Cases \\
\hline stragy*scope*ECONHU*demo*orga*integ & 0.896 & 0.287 & GIL, \\
\hline stragy*scope*ECONHU*SOCHU*demo*integ & 0.909 & 0.331 & CHT \\
\hline stragy*scope*ECONHU*SOCHU*orga*integ & & & MIN \\
& 0.872 & 0.302 & CHT, \\
& & & BOD, \\
\hline
\end{tabular}




\begin{tabular}{|l|l|l|l|}
\hline stragy*SCOPE*ECONHU* ${ }^{*}$ sochu*DEMO*ORGA*INTEG & 0.967 & 0.097 & IRL \\
\hline stragy*SCOPE*ECONHU*SOCHU*demo*orga*INTEG & 1.000 & 0.141 & KUR \\
\hline
\end{tabular}

Table 11: Analysis of necessary conditions in the institutional model for successful autonomies.

\begin{tabular}{|l|l|l|l|}
\hline & Consistency & RoN & Coverage \\
\hline PROP + DECEN & 0.910 & 0.527 & 0.660 \\
\hline
\end{tabular}

Table 12: Analysis of sufficient conditions in the institutional model for successful autonomies.

\begin{tabular}{|l|l|l|l|}
\hline & Consistency & Coverage & Cases \\
\hline RULE*DECEN*PROP & 0.787 & 0.369 & ALA, BAS, CAT \\
\hline
\end{tabular}

Table 13: Analysis of sufficient conditions in the institutional model for failed autonomies.

\begin{tabular}{|l|l|l|l|}
\hline & Consistency & Coverage & Cases \\
\hline prop & 0.644 & 0.649 & BOU, JAM, SAN, \\
& & & BOD, CHT, GIL, \\
& & & MIN; COR, IRL \\
\hline
\end{tabular}

Table 14: Analysis of sufficient conditions in the actor-specific model for failed autonomies (Consistency $=0.858$ and Coverage 0.443).

\begin{tabular}{|l|l|l|l|}
\hline & Consistency & Coverage & Cases \\
\hline NATIO*homog & 0.914 & 0.237 & BOD, JAM \\
\hline natio*TEK*HOMOG & 0.802 & 0.207 & ATL \\
\hline
\end{tabular}

Table 15: Analysis of Sufficient Conditions for the Model of Success with Consistency $=0.75$ and 0.9 .

\begin{tabular}{|l|l|l|l|}
\hline & Consistency & Coverage & Cases \\
\hline SCOPE*DEMOCR*INCL*natio*INTERN & 0.842 & 0.670 & $\begin{array}{l}\text { ALA, GAG, } \\
\text { TIR, ACH, } \\
\text { BAS, CAT, } \\
\text { CAL }\end{array}$ \\
\hline inequ*SCOPE*DEMOCR*INCL*natio*INTERN & 0.910 & 0.302 & $\begin{array}{l}\text { ALA, GAG, } \\
\text { TIR }\end{array}$ \\
\hline
\end{tabular}


Table 16: Analysis of Sufficient Conditions in the Empirical Model of Failure with Consistency = 0.9 .

\begin{tabular}{|c|c|c|c|}
\hline & Consistency & Coverage & Cases \\
\hline \multicolumn{4}{|l|}{ Conservative solution } \\
\hline INEQU*'stragy*scope*incl & 0.905 & 0.464 & BOD, CHT; GIL, JAM, COR, MIN \\
\hline \multicolumn{4}{|l|}{ Intermediate solution } \\
\hline INEQU* ${ }^{*}$ stragy* ${ }^{*}$ scope*incl & 0.905 & 0.464 & BOD, CHT; GIL, JAM, COR, MIN \\
\hline \multicolumn{4}{|l|}{ Parsimonious solution } \\
\hline stragy ${ }^{*}$ scope & 0.825 & 0.636 & BOD, CHT; GIL, JAM, COR, MIN \\
\hline scope*incl & 0.884 & 0.499 & BOD, CHT; GIL, JAM, COR, MIN \\
\hline
\end{tabular}

